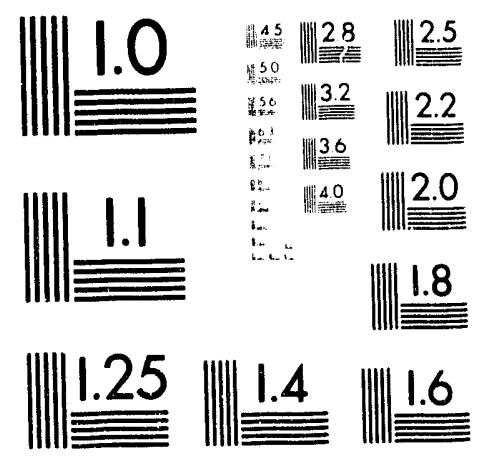



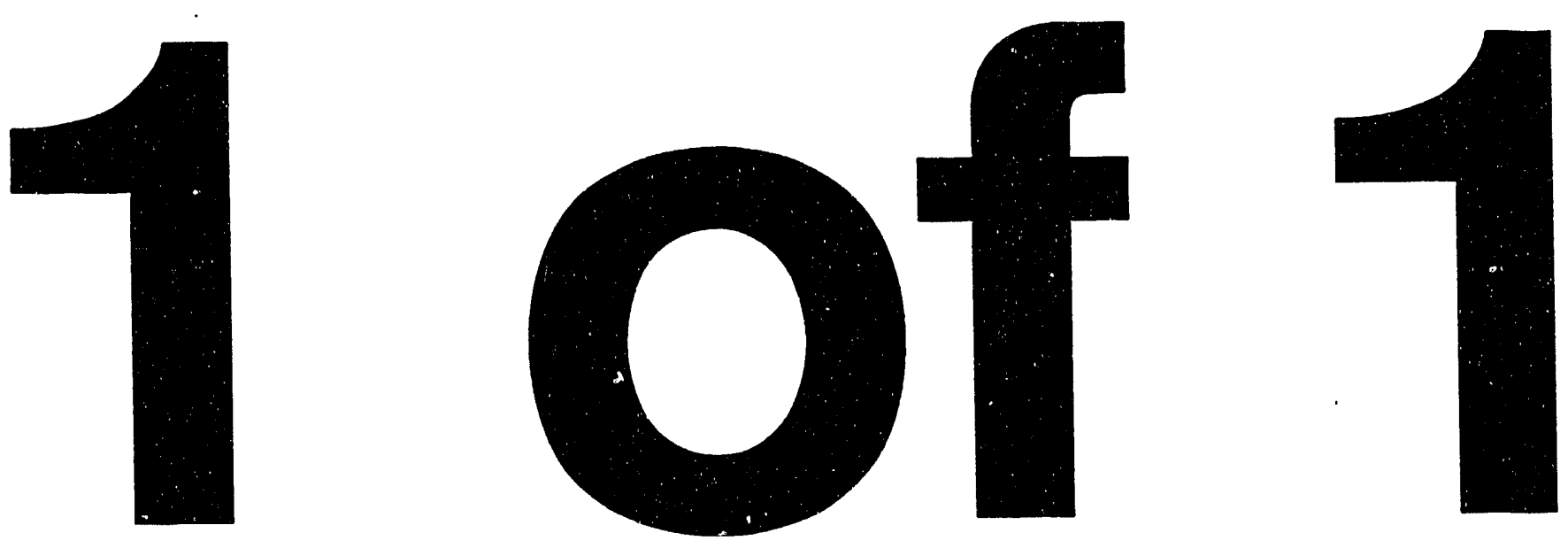
DOE/EIA-M053

\section{Model Documentation Report: Short-Term Hydroelectric Generation Model}

August 1993

Energy Information Administration
Office of Coal, Nuclear, Electric, and Alternate Fuels

U.S. Department of Energy

Washington, DC 20585 


\title{
Model Documentation Report: Short-Term Hydroelectric Generation Model
}

\author{
August 1993 \\ Energy Information Administration \\ Office of Coal, Nuclear, Electric, and Alternate Fuels \\ U.S. Department of Energy \\ Washington, DC 20585
}

This report was prepared by the Energy Information Administration, the independent statistical and analytical agency within the Department of Energy. The information contained herein should not be construed as advocating or reflecting any policy position of the Department of Energy or any other organization. 


\title{
Model Documentation Report: Short-Term Hydroelectric Generation Model
}

\author{
Introduction
}

\section{Purpose of the Report}

The purpose of this report is to define the objectives of the Short-Term Hydroelectric Generation Model (STHGM), describe its basic approach, and to provide details on the model structure. This report is intended as a reference document for model analysts, users, and the general public. Documentation of the model is in accordance with the Energy Information Administration's (EIA) legal obligation to provide adequate documentation in suppont of its models (Public Law 94-385, Section 57.b.2).

\section{Model Summary}

The STHGM performs a short-term (18 to 27-month) forecast of tiydroelectric generation in the United States using an autoregressive integrated moving average (ARIMA.) time series model with precipitation as an explanatory variable. The model results are used as input for the Short-Term Energy Outlook.

\section{Model Archival Citation}

The STHGM is archived on the Energy Information Administration mainframe system and is available through the sponsoring office. The model contact is:

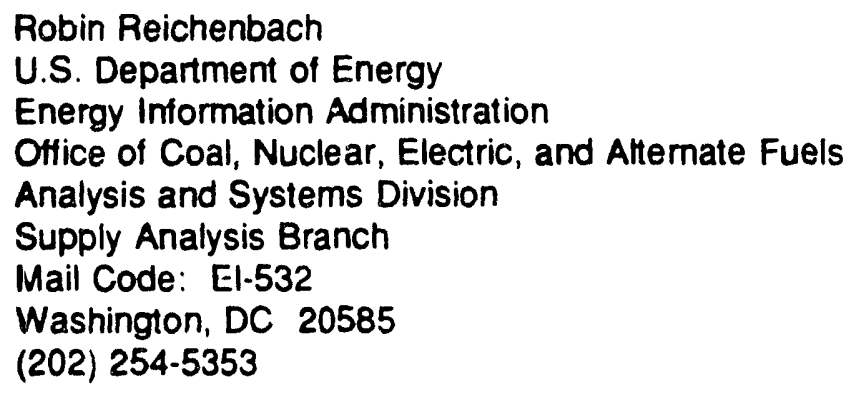

\section{Report Organization}

The remainder of this report is organized in the following manner: (1) model purpose, (2) model rationale, (3) model structure, (4) properties of the mathematical solution, (5) calibration and sensitivity analysis, (6) documentation of technical detail on the model data and equations, and (7) appendices.

\section{Model Purpose}

\section{Model Objectives}

The STHGM is used to provide quarterly projections of national hydroelectric generation for the Short-Term Energy Outlook. The model uses an ARIMA time series model with explanatory variables, otherwise known as a transfer function model, ${ }^{\prime}$ as the basis for its forecasting. The model is based on 23 years of monthly historic data from 1970 
to 1992. The model also incorporates variations in precipitation as an explanatory variable.

\section{Model InputlOutput}

The STHGM uses both DOE and non-DOE data input sources. The DOE data are national totals of the plant-level net hydroelectric generation data reported monthly on the Form ElA-759, "Monthly Power Plant Report," and its predecessors. The non-DOE data are monthly precipitation data from the National Climatic Data Center. ${ }^{2}$

Forecasts of precipitation data are also required for the model, due to the modelling assumption of "normal" precipitation. The 57-year monthly averages from the National Climatic Data Center are used as the forecasted "normal" precipitation."

The output data is an 18 to 27 -month forecast of net hydroelectric generation.

\section{Relationship to Other Models}

The STHGM does not directly interface with other EIA models; however, its forecast is utilized as input in the ShortTerm Integrated Forecasting System (STIFS). The hydroelectric forecast is independent of other renewable and nuclear generation forecasts, but it does have an impact on the fossil fuel generation forecasts as an input to STIFS.

\section{Mode! Rationale}

\section{The Time Series Approach}

Time series models predict future generation as a function of past generation and account for trends and seasonality. No use is made of engineering knowledge or economic concepts in these models. Since a seasonal pattern is observed in historical monthly net hydroelectric generation data and the level of generation is affected by the availability of water, the STHGM is designed as an ARIMA time series model with the addition of one explanatory variable, precipitation.

\section{Assumptions}

The STHGM uses an ARIMA time series model with precipitation as an explanatory variable. The model is based on normal ARIMA modelling assumptions. That is, the data are assumed to follow a model which is linear and time invariant with constant coefficients. Fixed monthly values are used to describe seasonality. Precipitation is assumed to be "normal" from the last month of available data fonward. A 57-year average for precipitation in the given calendar month is the assumed "normal" precipitation for that month.

\section{Alternative Approaches}

The previous approach for forecasting hydroelectric generation used by the Energy Information Administration was to use a purposive sample. For each month during the current water year, which ends September 30 , or a nine-month period from presently available data if longer, hydroelectric generation projections were based upon information obtained by phone from 10 utilities/organizations representing eight U.S. geographic regions (Table 1). Generation in each region was projected to change by the same percentage as generation for the sample. That is, estimations for each of the forecast months was determined by calculating a monthly ratio of each utility's projected generation

\footnotetext{
21970-1987: National Climatic Data Center, State, Regional, and National Monthly and Annual Precipitation Weighted by Area for the Contiguous United States January 1931 - December 1987 (Asheville, NC, August 1988), p. 66. 1988-1992: National Climatic Data Center, Monthly State, Regional and National Heating Degree Days Weighted by Population (Asheville, NC, March, 1989 through 1993), Table 3.3, "Regional and National Average Precipitation."

${ }^{3}$ National Climatic Data Center, State, Regional, and National Monthly and Annual Precipitation Weighted by Area for the Contiguous United States January 1931 - December 1987 (Asheville, NC, August 1988), p. 66.
} 


\section{Table 1. Hydroelectric Senerating Regions}

\begin{tabular}{l|l}
\hline Region & State \\
\hline 1 & $\begin{array}{l}\text { Connecticut, Delaware, District of Columbia, Maine, Massachusetts, New Hampshire, New } \\
\text { Jersey, New York, Pennsyivania, Rhode Island, Vermont. }\end{array}$ \\
2 & $\begin{array}{l}\text { Alabarra, Florida, Georgia, Kentucky, Maryland, Mississippi, North Carolina, Soutt. Carolina, } \\
\text { Tennessee, Virginia, West Virginia, Ala'Ka, Hawaii. }\end{array}$ \\
3 & California. \\
4 & Arizona, Colorado, Nevada, New Mexico, Utah. \\
6 & Idaho, Oregon, Washington. \\
7 & Arkansas, Illinois, Indiana, lowa, Kansas, Louisiaria, Michigan, Minnesota, Missouri, Onio, \\
8 & Oklahoma, Texas, Wisconsin. \\
& Montana, Wyoming.
\end{tabular}

to its actual generation in the past year. This ratio was applied to the region's generation for the pievious year to arrive at a projected value for the corresponding month of the current year. The regional projections were aggregated to obtain a national projection for gerieration.

Hydroelectric generation in the succeeding years was assumed to be normal. Normal generation was calculated for conventional and pumped storage units by using capacity information from the Form ElA-860, "Annual Electric Generator Report," and historical monthly capacity factors averaged over ten years.

This methodology included a considerable amount of analyst judgement: the assessment of patterns and other factors, such as precipitation, weather, demand, or market conditions. Another shortcoming of this method was that ditterent methodologies were used by the different sampled organizations.

In the development of the STHGM, the specitic form of the model used for forecasting was selected from among reasonable alternatives of the same form including the use of regular and seasonal differenciry. Additionally, an alternative to the use of monthly dummies to explain seasonality was considered. First the periodogram of the generation data was examined and the seasonal frequencies having the greatest impact were selected. The seasonal mean was defined to be the sum of estimated coefficients multiplying the sine and cosine functions having these selected periodicities. The monthly durnmy variable approach was adopted because it gave smaller root mean square error forecasts in the out of sample forecast evaluations (described in Calibration and Sensitiviiy Analysis, p. 7).

Another approach that was examined included the effects of trading day variations. The historic hydroelectric generation data were tested for trading day variation using the procedure X11 in SAS. The purpose of this test was to determine if the data needed to be adjusted for trading days, i.e. do hydroelectric facilities generate more on a Monday than on a Sunday. Any month can be looked at as having 28 days plus 0 to 3 extra ditferent days of the week. Depending upon which days are extra, i.e. Monday and Tuesday or Saturday and Sunday, the net hydroelectric generation in a month could be affected. Tests at the 5 percent level indicated some trading day effect with the lowest generation on Sundays and the largest on Mondays and Tuesdays (Table 2). Tests ot regional trading day variation using hydroelectric generation data for the ten Census Divisions (Appendix C) indicated that while some trading day effect was noticeable, it was negligible. Therefore, the national data were not adjusted for trading day variation.

Another approach which has not yet been examined is to use knowledge of current precipitation conditions instead of assuming normal precipitation throughout the forecast period. That is, the model could be modified to use average precipitation for low years or high years for sensitivity analysis. 
Table 2. National Tracting Day Varlation Output

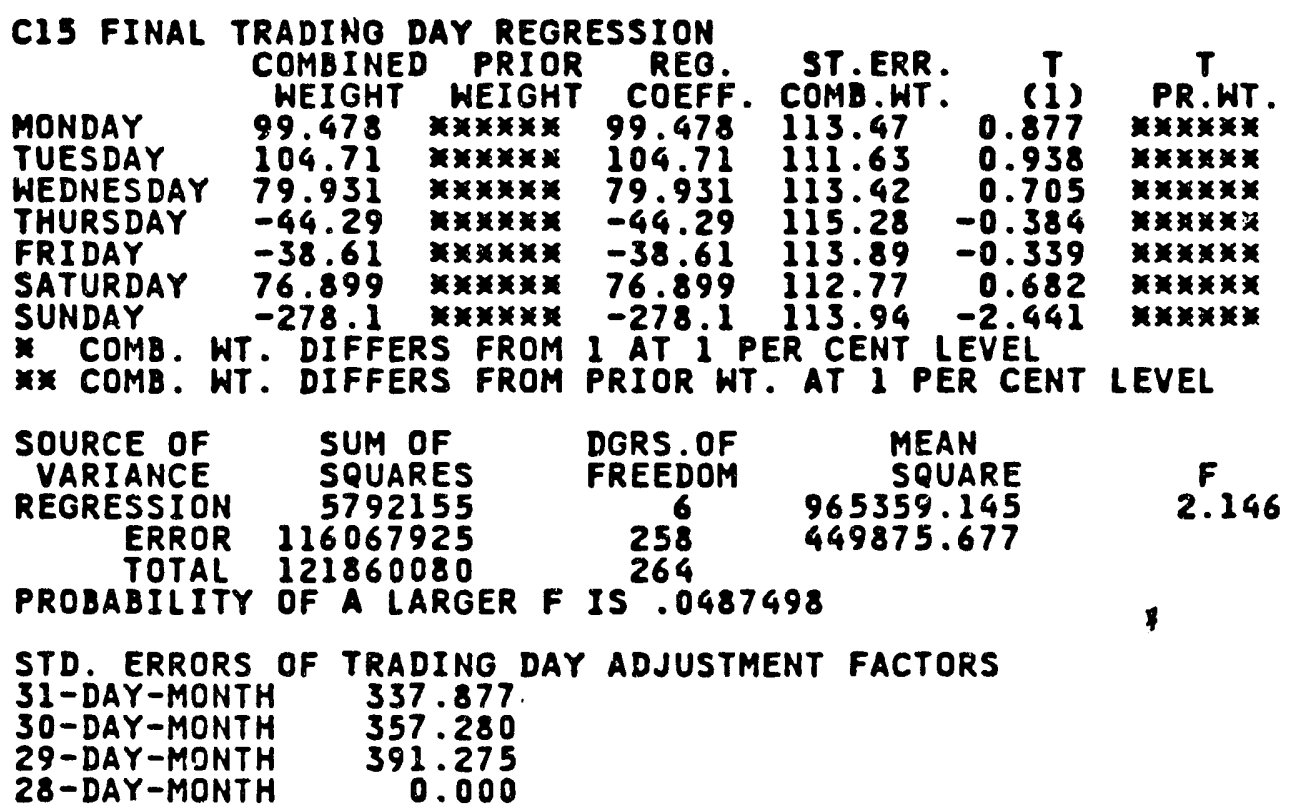




\section{Model Structure}

\section{Flow Diagram}

The initial step of the STHGM is reading in the historical net hydroelectric generation and precipitation data. The data are divided by the number of days in each month in order to account for the different lengths of the months. Next the first ARIMA procedure is run to estimate coefficients for the monthly dummy variables and the correlated lags of the precipitation data. The generation data are then adjusted using these coefficients to account for seasonality and the effects of precipitation. The ARIMA procedure is then run with the adjusted data which outputs the forecast. The forecast is multiplied by the number of days in each month and readjusted for seasonality and the effects of precipitation (Figure 1).

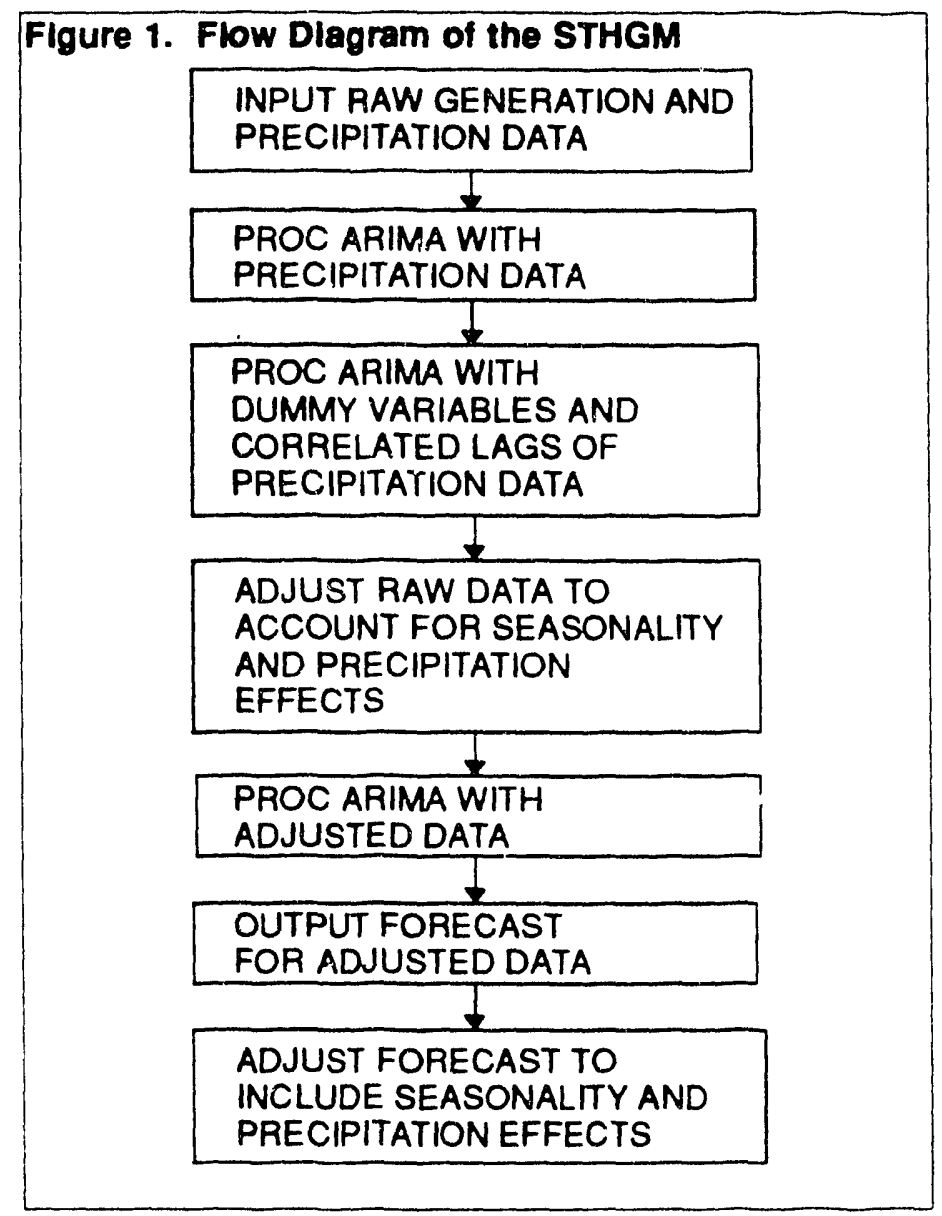

\section{List of Computations and Equations}

The time series models considered for this project come from the ARIMA family of models with explanatory variables. Model identification and estimation were done using PROC ARIMA in SAS version 6.07. In particular the model structure is of the form

$$
\Phi(B)\left(N A T I O N A L_{1}-\sum_{k=1}^{12} N U M_{k 01} D U M_{t, k}-v(B) \text { RAINNAT) }=\Theta(B) a_{1}\right.
$$


where,

NATIONAL, is the national daily average hydro generation in month $t$;

DUM $_{t, k}$ is a seasonal dummy variable which is zero unless observation $t$ is in month $k$, in which case it is one;

RAINNAT, is the national daily average precipitation in month $t$;

$\phi(B)$ is the autoregressive part of the model (Equation 6):

$\theta(B)$ is the moving average part of the model (Equation 7);

$v(B)$ is the transfer function part of the model (Equation 3); and

NUM $_{k+1}$ are the coefficients of the seasonal mean, where $k=1$ is the coefficient for January.

Specific model structure was selected from this family of models based on standard diagnostics: the autocorrelation function, partial autocorrelation function, and inverse autocorrelation function of both the generation data and the model residuals, significant t-statistics for estimated parameters, the Portmanteau goodness of fit Chi square test for departures from model assumptions, the Akaike Information Criterion (AIC) to select the best from competing models, and comparisons of the model forecasts to actual data otherwise known as out-of-sample testing."

The specific estimated parameters are shown in Table 3.

This model includes two functions which explain the time varying mean of the generation data: the first is the mean due to seasonal variation, the second is the mean due to the impact of precipitation. In particular, the average seasonal effect in month $t$ is given by

$$
\text { MEANS, }-\sum_{k=1}^{12} \text { NUM }_{k}, D_{1} M_{t, k}
$$

Where $N_{U} M_{k+1}$ is the estimated parameter (Table 3) and DUM $M_{t, k}$ is unchanged. The variance of the estimated seasonal mean in a month, VARS, is the square of the approximate standard error of the appropriate estimated coefficient (Table 3).

The transfer function part of the model describes the impact of precipitation on hydroelectric generation. This relationship is given formally by

$$
\text { MEANR, - V(B)RAINNAT }
$$

Using the estimated coefficients (Table 3 ) it is written specifically

$$
\begin{gathered}
\text { MEANR }_{t}=896.22 \text { RAINNAT }_{t}-834.26 \text { RAINNAT }_{+1}-526.13 \text { RAINNAT }_{+2}- \\
\\
262.03 \text { RAINNAT }_{18}-171.29 \text { RAINNAT }_{19} .
\end{gathered}
$$

The variance of the estimated mean of the changes in precipitation is given by

$$
\begin{gathered}
\text { VARR }_{t}=\left(140.39 \text { RAINNAT }_{t}\right)^{2}-\left(145.49 \text { RAINNAT }_{+1}\right)^{2}+\left(139.87 \text { RAINNAT }_{+2}\right)^{2} \\
-\left(130.23 \text { RAINNAT } T_{-8}\right)^{2}+\left(131.45 \text { RAINNAT } T_{+\theta}\right)^{2}
\end{gathered}
$$

where the approximate standard errors of the estimated coefficients come from Table 3.

'For more information, see: Sas Institute Inc., SAS/ETS User's Guide, Version 6 (Cary, NC, January 1989). 
Table 3. ARIMA Output Containing Estimated Dummy Varlable and Preclpltation Lag Parameters

$$
\text { ARIMA Proceduro }
$$

Maximum Likelihood Estimation

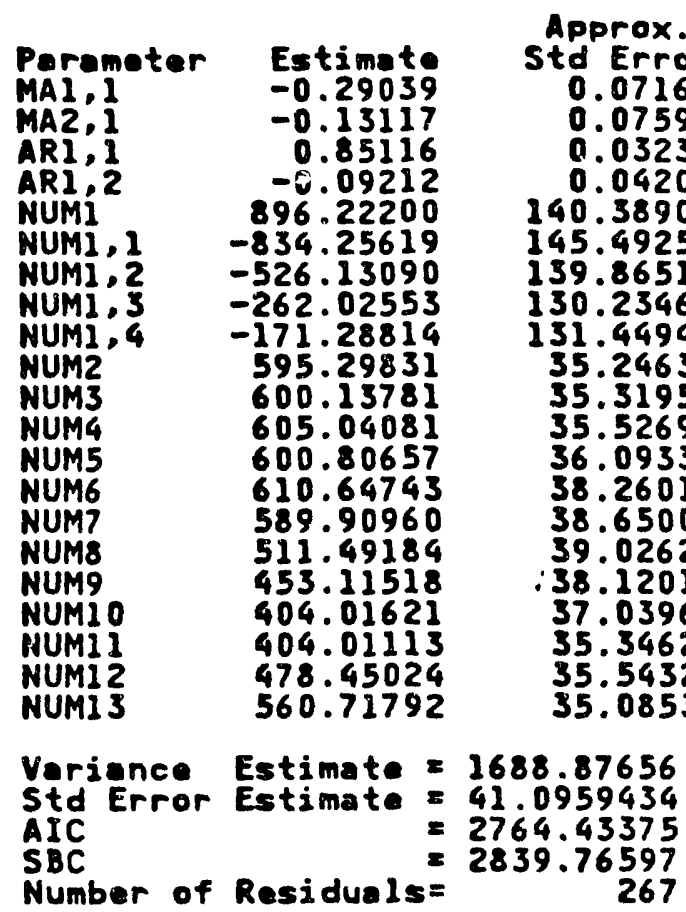

Autocorrelation Check of Residuals

\begin{tabular}{|c|c|c|c|c|c|c|c|c|c|}
\hline \multirow[b]{2}{*}{$\begin{array}{l}\text { To } \\
\text { Lo } \\
6 \\
12 \\
18 \\
24 \\
30 \\
36 \\
42\end{array}$} & \multirow[b]{2}{*}{$\begin{array}{r}\text { Chi } \\
\text { square } \\
4.31 \\
7.77 \\
14.07 \\
20.55 \\
22.18 \\
27.30 \\
36.22\end{array}$} & \multirow[b]{2}{*}{$\begin{array}{r}\text { DF } \\
2 \\
8 \\
14 \\
20 \\
26 \\
32 \\
38\end{array}$} & \multirow[b]{2}{*}{$\begin{array}{l}\text { Prob } \\
0.116 \\
0.456 \\
0.444 \\
0.424 \\
0.679 \\
0.703 \\
0.552\end{array}$} & \multicolumn{4}{|c|}{ Autocorrelations } & \multirow[b]{2}{*}{$\begin{array}{r}0.060 \\
-0.078 \\
0.010 \\
-0.011 \\
-0.037 \\
-0.085 \\
-0.009\end{array}$} & \\
\hline & & & & $\begin{array}{r}0.029 \\
0.030 \\
0.018 \\
0.043 \\
-0.032 \\
-0.004\end{array}$ & $\begin{array}{r}-0.002 \\
0.001 \\
0.080 \\
0.024 \\
0.041 \\
0.065\end{array}$ & $\begin{array}{r}-0.058 \\
-0.066 \\
-0.099 \\
0.074 \\
-0.004 \\
-0.017 \\
-0.011\end{array}$ & $\begin{array}{r}0.029 \\
0.025 \\
-0.054 \\
-0.005 \\
-0.030 \\
-0.023 \\
-0.136\end{array}$ & & \\
\hline
\end{tabular}

For purposes of forecasting generation, these two mean functions are subtracted from the past generation data, the autoregressive and moving average parts of the model (Table 3) are reestimated, and used to forecast :8 to 27 months ahead. MEANS, the seasonal effects on the generation, is calculated for the forecasts using the known dummy variables each representing a month. MEANR, the impact of precipitation on the generation, is calculated for the forecasts using the actual precipitation for past months which is still affecting generation in the forecast period and a 57-year average monthly precipitation as the monthly forecasts. These impacts are then added to the forecasts from ARIMA. The estimated torecast variance from ARIMA is added to VARS, and VARR, the variances of the estimated seasonal and precipltation effects, and is used to calculated 95 percent confidence intervals for the forecasts. 
The autoregressive part of the model using coefficients given by AR (Table 3 ) is

$$
\Phi(B)=\left(1-0.85 B-0.09 B^{11}\right)
$$

The moving average part of the model using coefficients given by MA (Table 3 ) is

$$
\theta(B)=\left(1+0.29 B^{13}\right)\left(1+0.13 B^{12}\right)
$$

After specifying the model for the ARIMA procedure, the procedure automatically makes use of these formulas in calculating the forecasts. 


\section{Properties of the Mathematical Solution}

\section{Theoretical Considerations}

Sie Assumptions, Alternative Approaches, and List of Computations and Equations.

\section{Subject-Matter Considerations}

Because the hydroelectric generation data exhibits seasonality, the STHGM uses dummy variables each representing a month to account for seasonality. Seasonality needs to be accounted for in the raw data in order for the time series model to reflect it in the forecasts.

Precipitation is an explanatory variable to the time series model because of the dependency of hydroelectric generation on precipitation historically. Precipitation le:'sls determine the availability of water in reservoirs for electricity generation, as well as the effects of recent rain or snow on run-of-river hydroelectric facilities. Average preciphation is used during the forecast period for hydroelectric generation which is consistent with the assumption of normal weather for the STEO forecasts.

\section{Calibration and Sensitivity Analysis}

\section{Results of Calibration}

Evaluation of the model was performed using out-of-sample tests. Fiat is, several different periods of actual data were deleted from the input data, the parameters in the model were reestimated, and forecasts made as described above for a 24-month period. These forecasts were compared to actual data and past forecasts for the Short-Term Energy Outlook based on the same historical data.

The first comparison was to graph the out-of-sample results (Figures 2, 3, and 4). From the graphs, the following conclusions are illustrated: (1) the STHGM forecast is in general closer to the actual generation than the previous STEO forecasts; (2) the 1990 and 1991 actual data are close to the long run average hydroelectric generation and the STHGM forecasts for these years is generally within 1 to 2 billion kilowathours of the actual generation; (3) for 1992, an unusually low year for hydroelectric generation, both forecasts are not as good as for 1990 and 1991 , which can be explained by the forecast assumption of normal precipitation and the fact that precipitation was below normal in $1992 ;(4)$ in 1992, with the below normal hydroelectric generation, the STHGM still provides a closer forecast than used in the STEO, and (5) as the input data gets closer to 1992, the STHGM forecasts improved for 1992.

The second comparison was with the Root Mean Square Errors (RMSE) oi the model runs (Table 4), where $n$ is the number of months of the forecast included in the calculation and

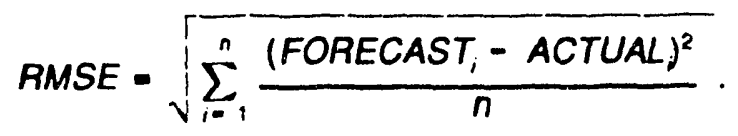

In all cases the RMSE of the STHGM is smaller than the RMSE of the STEO forecasts. The RMSES show the improvement of both forecasts for a particular year as the input data gets closer to that year. 
Figure 2. Out of Sample and STEO Forecasts Using Actual Data through 1989 Compared to Actual Data, 1990 and 1991.

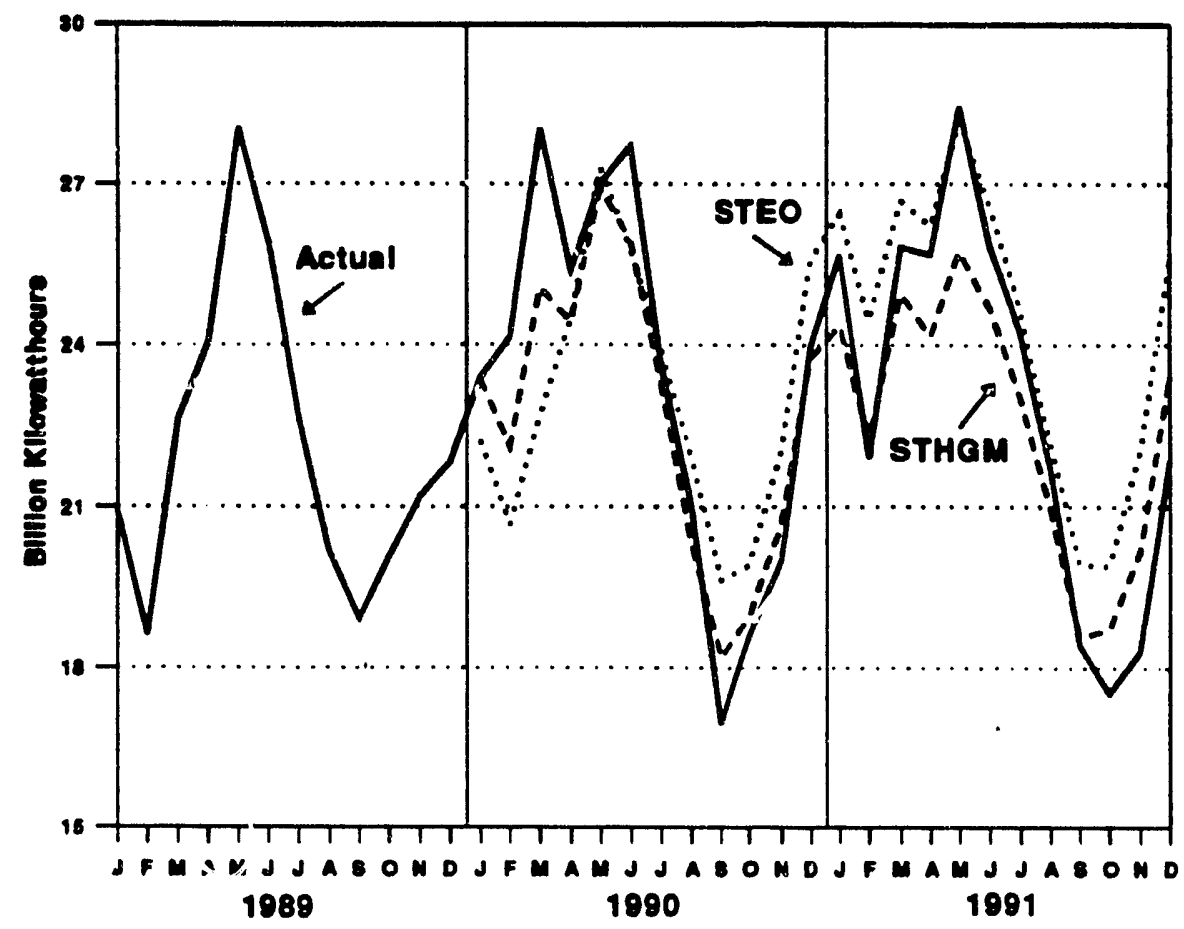

Notes: -All forecasts are based on actual generation and precipitation data through the indicated year. -All torecasts assume normal precipitation during the iorecast period. -Data shown in Table C1.

Source '8TEO Foncasta: Energy Information Administration, Office of Coal, Nuclear, F!actric, and Atemate Fuels memo to Office of Energy Markets and End Use dated March 13, 1990. 8THGM Forecests: Energy information Administration, STHGM run using HYDRO.TIME.SERIES. FINAL.D060193. Actual: Energy Intormation Administration, Form ElA-759, "Monthly Power Plant Report." 
Figure 3. Out of Sample and STEO Forecasts Using Actual Data through 1990 Compared to Actual Data, 1991 and 1992.

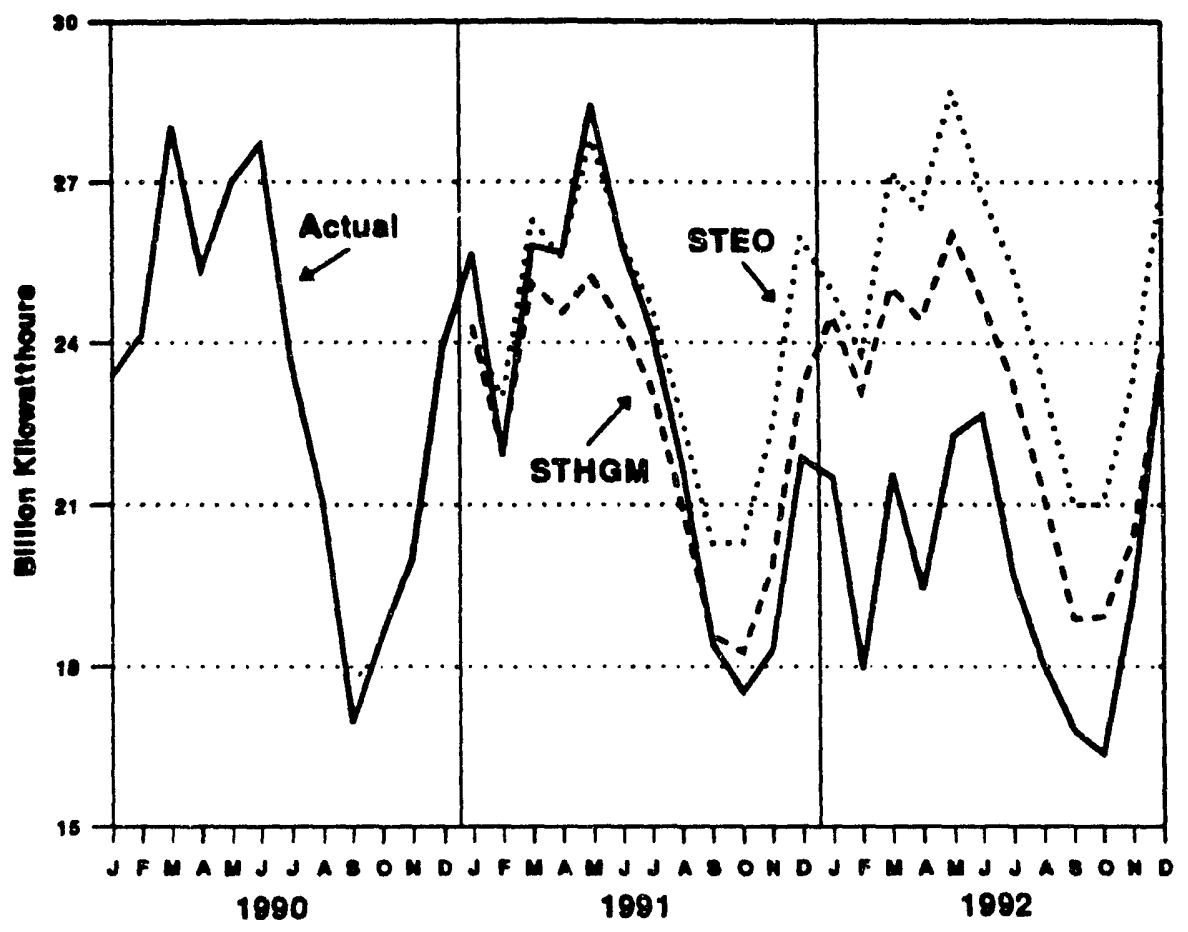

Notes: -All torecasts are based on actual generation and precipitation data through the indicated year. -All torecasts assume normal precipitation during the forecast period. - Data shown in Table C2.

SOurce: STEO Forecasts: Energy Information Administration, Otice of Coal, Nuclear, Electric, and Niternate Fuels memo to OHice of Energy Markets and End Use dated March 19, 1991. STHGM Forecasts: Energy Information Administration, STHGM run using HYDRO.TIME.SERIES.FINAL.D060193. Actual: Energy Information Administration, Form EIA-759, "Monthly Power Plant Report." 
Figure 4. Out of Sample and STEO Forecasts Using Actual Data through 1991 Compared to Actual Data, 1992 and 1993.

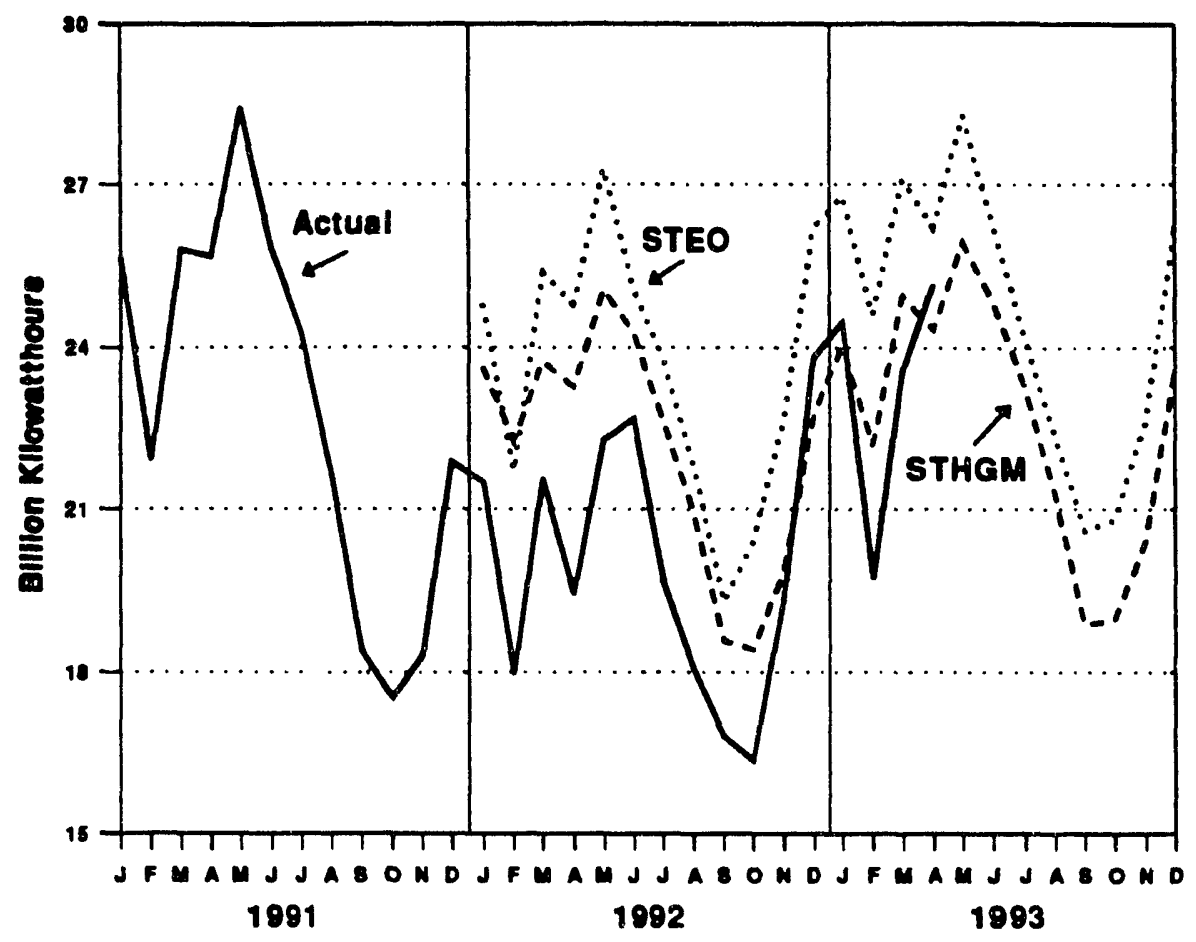

Notes: -All forecasts are based on actual generation and precipitation data through the indicated year. -All forecasts assume normal precipitation during the forecast period. - Data shown in Table C3.

Source: STEO Forecasts: Energy Information Administration, Office of Coal, Nuclear, Electric, and Altemate Fuets memo to Office of Energy Markets and End Use dated March 6, 1992. STHGM Forecasts: Energy information Administration. STHGM run using HYDRO.TIME.SERIES.FINAL.D060193. Actual:

Energy Information Administration, Form ElA-759, "Monthly Power Plant Report." 
Table 4. Comparison of Root Mean Square Errors.

\begin{tabular}{r|c|c|c}
\hline \multirow{2}{*}{$\begin{array}{r}\text { Using Historical } \\
\text { Deta through: }\end{array}$} & $\begin{array}{c}\text { Year(s) of Forecast } \\
\text { Included in the RMSE }\end{array}$ & STHGM & RMSE \\
\cline { 3 - 4 } & 1990 & 1,267 & 2,289 \\
\hline $1989:$ & 1991 & 1,367 & 1,923 \\
& 1990 and 1991 & 1,318 & 2,114 \\
& $1990:$ & 1,363 & 2,040 \\
& 1991 & 3,280 & 5,092 \\
& 1992 & 2,511 & 3,879 \\
& 1991 and 1992 & 2,597 & 3,749 \\
\hline
\end{tabular}

Notes: - All torecasts are based on actual generation and precipitation data through the indicated year. -All forecasts assume nomal precipitation during the forecast period.

STEO Forecests: Energy Information Administration, OH'ice of Coal, Nuclear, Electric, and Altemate Fuels memos to Source: 8TEO Forccests: Energy Intormation Ad 13, 1990, March 19, 1991, and March 6, 1892. STHGM Forecests: Energy

Office of Energy Markets and End Use dated March 


\section{Documentation of Technical Detail on the Model Data and Equations}

\section{Description of Input Data}

Input hydroelectric generation data for the STHGM is from archived databases of the Form ElA-759, "Monthly Power Plant Report," from 1970 through 1992. Data prior to 1978 may differ from published data due to unreturned forms that were estimated in the published data. The differences in the published data and the database is generally less than 0.1 percent; and, therefore, the database was used.

Once the model has read in the generation data, the data are divided by the number of days in each month in order to account for the different lengths of the months. Once the time series procedure is completed, the forecast of average daily generation is multiplied by the number of days in each month to produce estimates of monthly generation.

The monthly input precipitation data from 1970 to 1992 and the 57-year average precipitation data are from the National Climatic Data Center. These numbers were hand typed into the needed format. Forecasted precipitation data are the monthly averages for the 57-year period from 1931 to 1987 from the National Climatic Data Center. ${ }^{5}$ The precipitation data, like the generation data, was adjusted to account for the number of days in the month.

\section{Non-DOE Input Sources}

- 1970-1987 and Average: National Climatic Data Center, State, Regional, and National Monthly and Annual Precipitation Weighted by Area for the Contiguous United States January 1931 - December 1987 (Asheville, NC, August 1988), p.66. 1988-1992: Monthly State, Regional and National Heating Degree Days Weighted by Population (Asheville, NC, March, 1989 through 1993), Table 3.3, "Regional and National Average Precipitation."

- National precipitation data.

\section{DOE Data Input Sources}

- Energy Information Administration, Databases for Form ElA-759, "Monthly Power Plant Report," and predecessors.

- Hydroelectric generation data.

\section{ARIMA Output Providing Coefficient Estimates}

The coefficient estimates and a number of statistics related to the goodness-of-fit of the equations estimated by the STHGM are listed in Table 3.

\footnotetext{
${ }^{5}$ National Climatic Data Center, State, Regional, and National Monthly and Annual Precipitation Weighted by Area for the Contiguous United States January 1931 - December 1987 (Asheville, NC, August 1988), p. 66.
} 


\section{Appendix A. Model Abstract}

Model Name: Short-Term Hydroelectric Generation Model

Model Acronym: STHGM

Model Description: The STHGM performs a short-term (18 to 27-month) forecast of hydroelectric generation in the United States using an autoregressive integrated moving average (ARIMA) time series model with precipitation as an explanatory variable. The model results are used as input for the Short-Term Energy Outlook.

Last Model Update: May 1993

Part of Another Model: None.

Model Intertaces: None. Results used as independent input into the Short-Term Integrated Forecasting System (STIFS).

\section{Sponsor:}

- Office: Office of Coal, Nuclear, Electric and Alternate Fuels.

- Division: Analysis and Systems Division.

- Branch: Supply Analysis Branch, El-532.

- Model Contact: Robin Reichenbach.

- Telephone: 202-254-5353.

Documentation: Energy Information Administration, "Model Documentation Report: Short-Term Hydroelectric Generation Model."

Archlve Media and Installation Guldes: Archived on Energy Information Admiristration mainframe system under the name "HYDRO.TIME.SERIES.FINAL.D060193" on account RR56434. The model is written in SAS version 6.07.

Purpose: The STHGM is to be used for general forecasting purposes to provicle quarterly projections of monthly national hydroelectric generation for the Short-Term Energy Outlook.

Energy Systems Described by Model: National hydroelectric generation.

\section{Coverage:}

- Geographic: National.

- Time Unit/Frequency: Monthly.

- Products: Hydroelectric Generation. 


\section{Modelling Features:}

- Model Structure: Autoregressive integrated moving average (ARIMA) time series model with an explanatory variable.

- Modelling Technique: Time series analysis.

- Special Features: None.

\section{Non-DOE Input Sources}

- 1970-1987 and Average: National Climatic Data Center, State, Regional, and National Monthly and Annual Precipitation Weighted by Area for the Contiguous United States January 1931 - December 1987 (Asheville, NC, August 1988), p.66. 1988-1992: Monthly State, Regional and National Heating Degree Days Weighted by Population (Asheville, NC, March, 1989 through 1993), Table 3.3, "Regional and National Average Precipitation."

- National precipitation data.

\section{DOE Data Input Sources}

- Energy Information Administration, Databases for Form ElA-759, "Monthly Power Plant Repont," and predecessors.

- Hydroelectric generation data.

General Output Descriptions: STHGM is used to generate short-term (18 to 27-month), monthly forecasts of U.S. hydroelectric generation.

\section{Computing Environment:}

- Hardware Used: Energy Information Administration Mainframe System (Model Number IBM 3090).

- Operating System: MVS.

- Sottware Used: SAS version 6.07.

- Estimated Run Time: Approximately 15 seconds computer time on ElA Mainframe System.

- Special Features: None.

Independent Expert Revlews: None.

Status of Evaluations by Sponsor: On-going.

\section{Blbllography:}

- George E. Box and Gwilym Jenkins, Time Series Analysis, Forecasting and Control (1976).

- $\quad$ Sas Institute Inc., SAS/ETS User's Guide, Version 6 (Cary, NC, January 1989). 


\section{Appendix B. Source Code}

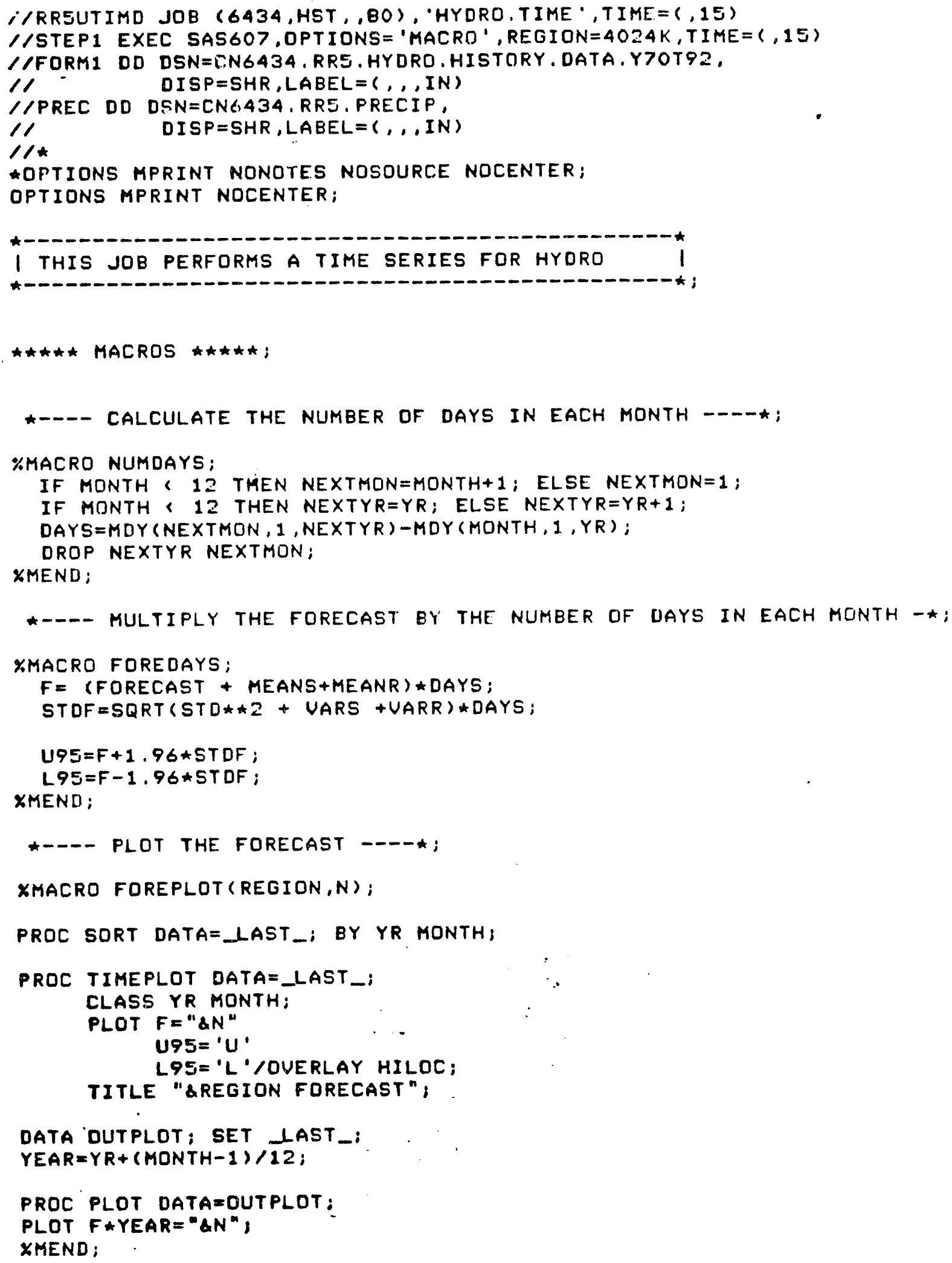




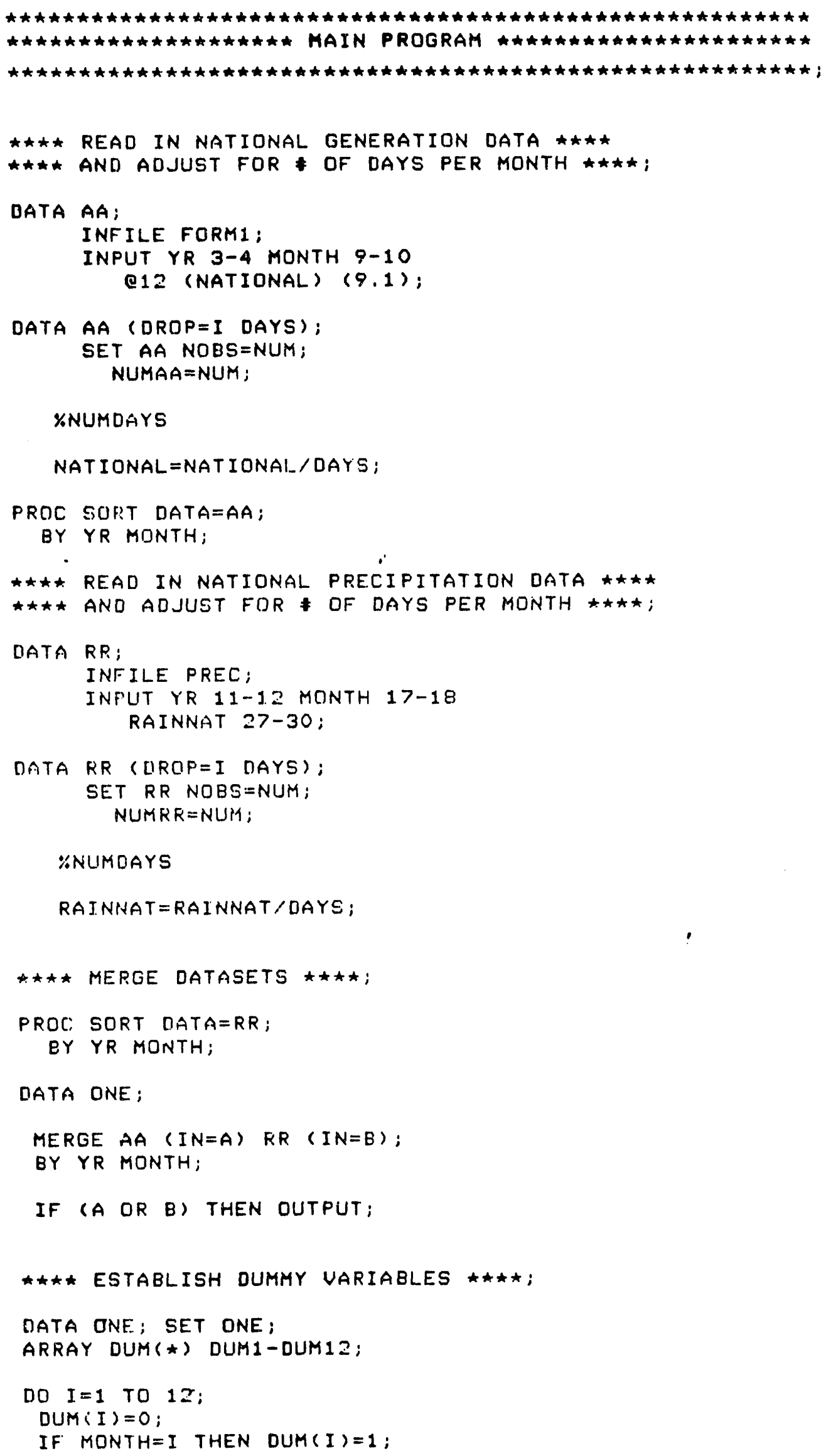




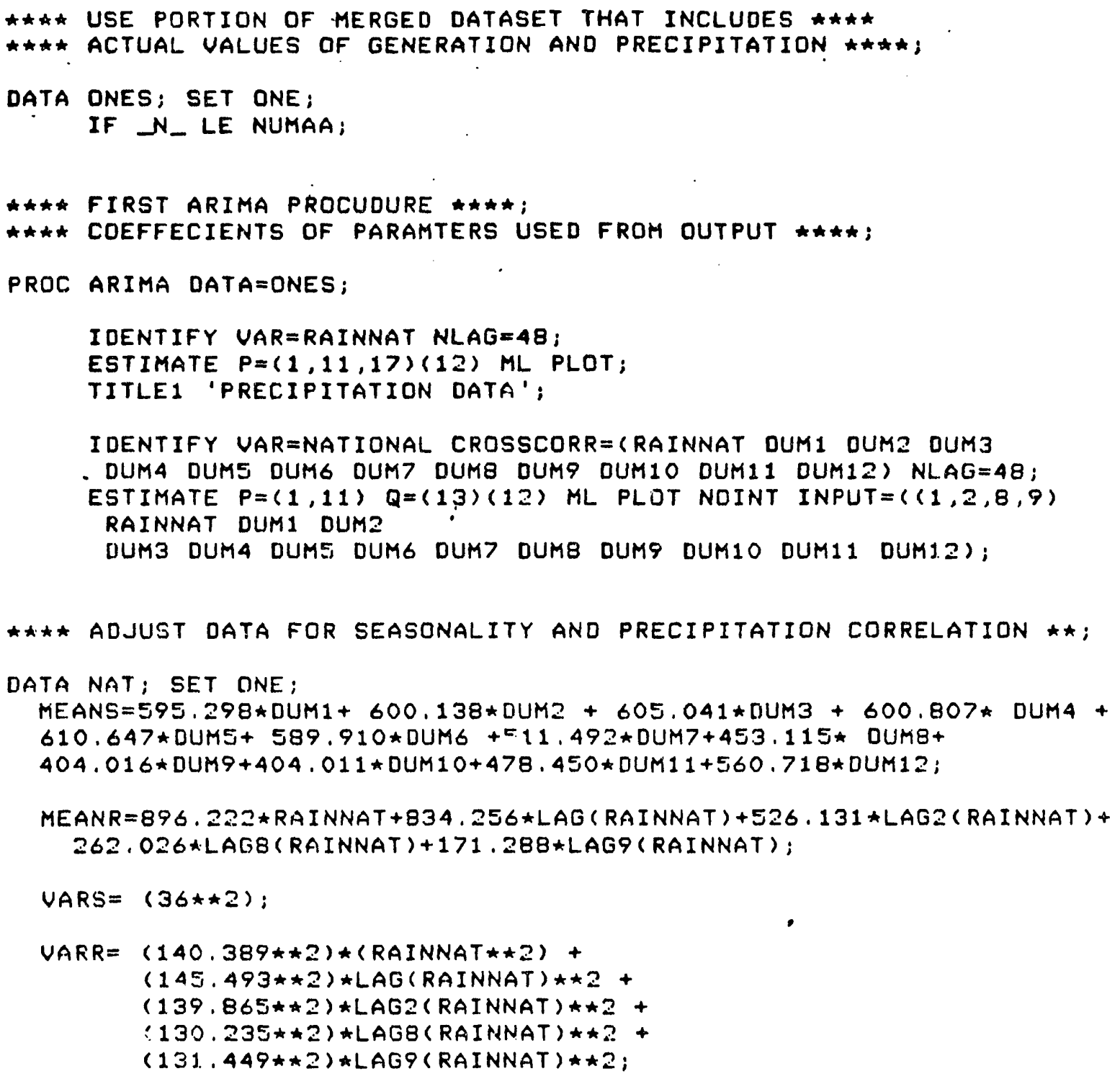

NEWNAT =NATIONAL - MEANS-MEANR;

DATA NATS; SET NAT;

IF _ N LE NUMAA;

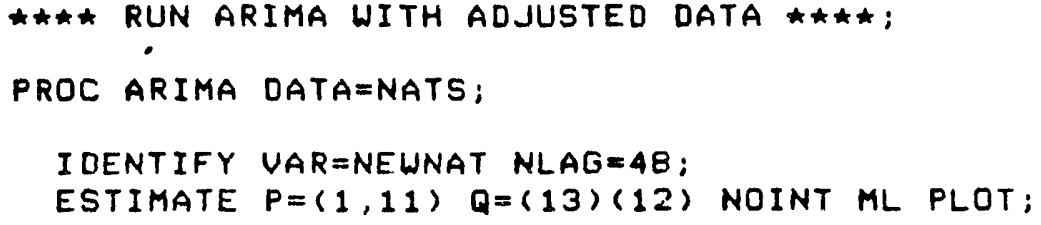




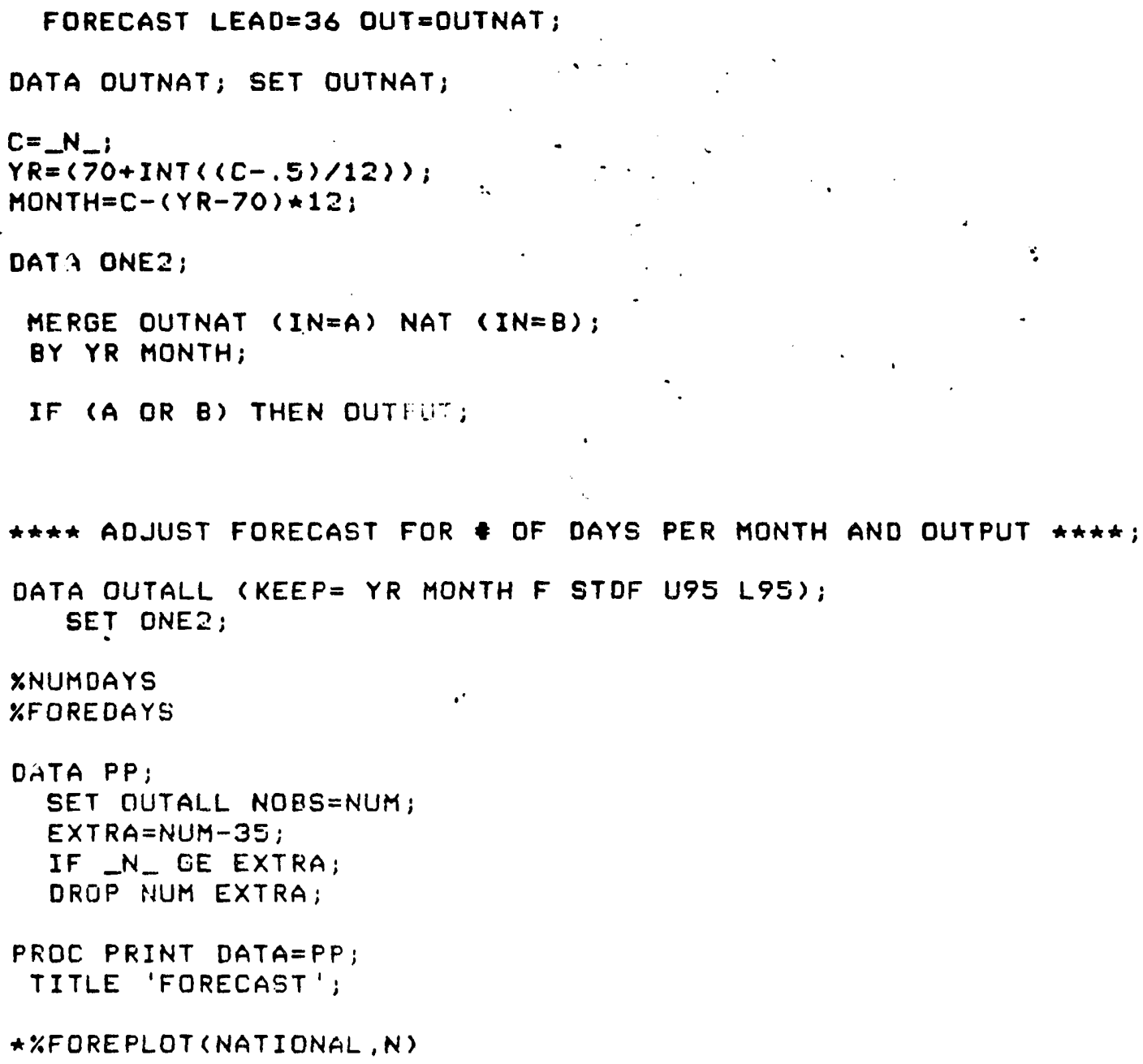




\section{Variable Definitions}

YR year

MONTH month

NATIONAL national hydroelectric generation data

NUMAA number of observations of national hydroelectric generation data

RAINNAT national precipitation data

NUMRR number of observations of national precipitation data

DAYS $k$ number of days in month $k$

DUM $_{t, k} \quad$ monthly dummy variables where $D U M_{t, k}=1$ if $t$ observed in morth $k$ and $D U M_{t, k}=0$ otherwise

MEANS average seasonal effect of the hydroelectric generation data; calculated using coefficients of the durnmy variables from the procedure ARIMA runs

MEANR average impact of past and present changes in precipitation; calculated using coefticients of the lags of the correlated precipitation data from the procedure ARIMA runs

VARS variance of the estimated seasonal mean of the hydroelectric generation data

VARR variance of the estimated mean of the changes in precipitation; calculated using the approximate standard eiror of the estimated coefticients from the procedure ARIMA runs

NEWNAT hydroelectric generation data which has been adjusted for the effects of seasonality and assumed nomal forecasted precipitation

F readjusted forecast for hydroelectric generation

FORECAST forecast of hydroelectric generation from the procedure ARIMA run on the adjusted hydroelectric generation data

STDF estimation of the standard deviation of the readjusted hydroelectric generation forecast

STD standard deviation for the hydroelectric generation from the procedure ARIMA run on thie adjusted hydroelectric generation data

U95

estimated upper 95 percent confidence interval for the readjusted hydroelectric generation forecast

L95 estimated lower 95 percent confidence interval for the readjusted hydroelectric generation forecast 


\section{Appendix C. Data}

Table C1. Out of Sample and STEO Forecasts Using Actual Data through 1989 with Actual Hydroelectric Generation, 1989-1991

\begin{tabular}{|c|c|c|c|c|}
\hline \multirow[b]{2}{*}{ Yoes } & \multirow[b]{2}{*}{ Month } & \multirow{2}{*}{$\begin{array}{c}\text { Net } \\
\text { Hodiodeciulc } \\
\text { Concretion }\end{array}$} & \multicolumn{2}{|c|}{ Forncenstas } \\
\hline & & & ETHOM & ETEO \\
\hline \multirow[t]{12}{*}{1089} & January & 20.9 & NA & NA \\
\hline & February & 18.6 & NA & NA \\
\hline & March & 22.6 & NA & NA \\
\hline & April & 24.1 & NA & $N A$ \\
\hline & May & 28.0 & NA & NA \\
\hline & June & 25.8 & NA & NA \\
\hline & July & 22.7 & NA & NA \\
\hline & August & 20.2 & NA & NA \\
\hline & September & 18.8 & NA & NA \\
\hline & October & 20.1 & NA & NA \\
\hline & November & 21.2 & NA & NA \\
\hline & Decomber & 21.8 & NA & NA \\
\hline \multirow[t]{12}{*}{1990} & January & 23.4 & 23.4 & 22.2 \\
\hline & Fobne:y & 24.2 & 22.1 & 20.7 \\
\hline & March & 28.0 & 25.1 & 22.7 \\
\hline & April & 25.4 & 24.4 & 24.5 \\
\hline & May & 27.0 & 26.9 & 27.3 \\
\hline & June & 27.7 & 26.0 & 25.8 \\
\hline & July & 23.7 & 23.3 & 23.8 \\
\hline & August & 21.0 & 20.4 & 21.8 \\
\hline & Soptember & 17.0 & 18.2 & 19.6 \\
\hline & October & 18.6 & 18.9 & 10.8 \\
\hline & November & 20.0 & 20.7 & 22.0 \\
\hline & December & 24.0 & 23.8 & 25.6 \\
\hline \multirow[t]{12}{*}{1991} & January & 25.7 & 24.4 & 26.5 \\
\hline & February & 21.8 & 22.3 & 24.5 \\
\hline & March & 25.8 & 24.9 & 26.7 \\
\hline & April & 25.7 & 24.2 & 26.2 \\
\hline & May & 28.5 & 25.7 & 28.2 \\
\hline & June & 25.8 & 24.7 & 26.6 \\
\hline & July & 24.3 & 23.1 & 24.7 \\
\hline & August & 21.7 & 21.0 & 22.2 \\
\hline & September & 18.4 & 18.6 & 10.9 \\
\hline & October & 17.5 & 18.7 & 10.8 \\
\hline & Nowember & 18.3 & 20.2 & 22.0 \\
\hline & Decomber & 21.0 & 23.4 & 25.6 \\
\hline
\end{tabular}

Notes: All forecasts are based on cculd generation and precifitation data through the indicated year. All forecasts essume normal precipitation during the forecest period.

Source: 8TEO Forveasts: Energy Information Administration, Office of Coal, Nuclear, Electric, and Altemate Fuels memo to Office of Energy Markets and End Use dated March 13,1090. BTHGM Forecasts: Energy Information Administration, STHGM run using HYDRO.TIME.SERIES.FINAL.D060193. Actual: Energy Intormation Administration, Form ElA.759, "Monthly Power Plant Roport." 
Table C2. Out of Sample and STEO Forecasts Using Actual Data thiough 1990 with Actual Hydroelectric Generation, 1990-1992

\begin{tabular}{|c|c|c|c|c|}
\hline \multirow[b]{2}{*}{ Yax } & \multirow[b]{2}{*}{ Momth } & \multirow{2}{*}{ 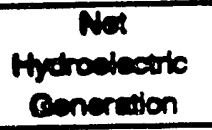 } & \multicolumn{2}{|c|}{ Forcents } \\
\hline & & & ETHCM & STEO \\
\hline \multirow{12}{*}{1990} & January & 23.4 & NA & NA \\
\hline & Fubruary & 24.2 & NA & NA \\
\hline & March & 28.0 & NA & NA \\
\hline & April & 25.4 & NA & NA \\
\hline & May & 27.0 & NA & NA \\
\hline & June & 27.7 & $N A$ & NA \\
\hline & suly & 23.7 & NA & NA \\
\hline & August & 21.0 & NA & NA \\
\hline & Soptember & 17.0 & NA & NA \\
\hline & October & 18.6 & $N A$ & NA \\
\hline & November & 20.0 & NA & NA \\
\hline & Docomber & 24.0 & NA & NA \\
\hline \multirow[t]{12}{*}{1991} & January & 25.7 & 24.4 & 24.2 \\
\hline & February & 21.8 & 22.0 & 23.0 \\
\hline & March & 25.8 & 25.1 & 26.3 \\
\hline & April & 25.7 & 24.5 & 26.6 \\
\hline & May & 28.5 & 25.2 & 27.8 \\
\hline & June & 25.8 & 24.3 & 25.9 \\
\hline & July & 24.3 & 23.3 & 24.7 \\
\hline & Augusi & 21.7 & 21.1 & 22.6 \\
\hline & September & 18.4 & 18.7 & 20.3 \\
\hline & October & 17.5 & 18.3 & 20.3 \\
\hline & November & 18.3 & 19.8 & 22.4 \\
\hline & December & 21.8 & 23.1 & 26.0 \\
\hline \multirow[t]{12}{*}{1992} & January & 21.5 & 24.5 & 25.0 \\
\hline & February & 18.0 & 23.1 & 23.6 \\
\hline & March & 21.6 & 25.1 & 27.2 \\
\hline & April & 19.5 & 24.4 & 26.5 \\
\hline & May & 22.3 & 26.0 & 28.7 \\
\hline & June & 22.7 & 24.8 & 26.8 \\
\hline & suly & 18.7 & 23.5 & 25.5 \\
\hline & August & 18.1 & 21.4 & 23.4 \\
\hline & Soptember & 16.8 & 18.0 & 21.0 \\
\hline & October & 16.4 & 19.0 & 21.0 \\
\hline & November & 10.3 & 20.4 & 23.2 \\
\hline & December & 23.8 & 23.5 & 26.9 \\
\hline
\end{tabular}

Notes: -All torecasts are besed on ectual generation and precipitation data through the indicated year. All torecasts essume normal precipitation during the forecest period.

SOurce: 8TEO Forecasts: Energy Intormation Administration, Office of Coal, Nuclear, Electric, and Atemate Fuets memo to Otfice of Energy Markets and End Use dated March 19, 1991. 8THGM Forecasts: Energy Intormation Administration, STHGM IS HYRO.TIME.SERIES.FINAL.D060183. Actual: Energy Information Administration, Form ElA-759. "Monthly Power Plant Roport." 
Table C3. Out of Sample and STEO Forecasts Using Actual Data through 1991 with Actual Hydroelectric Generation, 19y1-1993

\begin{tabular}{|c|c|c|c|c|}
\hline \multirow[b]{2}{*}{ rear } & \multirow[b]{2}{*}{ Momth } & \multirow{2}{*}{$\begin{array}{l}\text { Nat } \\
\text { Mydrodectic } \\
\text { Conerenon }\end{array}$} & \multicolumn{2}{|c|}{ Forecans } \\
\hline & & & ETHCM & ETEO \\
\hline \multirow[t]{12}{*}{1991} & January & 25.7 & NA & NA \\
\hline & February & 21.0 & NA & NA \\
\hline & March & 25.8 & NA & NA \\
\hline & April & 25.7 & NA & NA \\
\hline & May & 28.5 & NA & NA \\
\hline & June & 25.8 & NA & NA \\
\hline & wuly & 24.3 & NA & NA \\
\hline & August & 21.7 & NA & NA \\
\hline & Soptember & 18.4 & NA & NA \\
\hline & October & 17.5 & NA & NA \\
\hline & November & 18.3 & NA & NA \\
\hline & Decumber & 21.8 & NA & NA \\
\hline \multirow[t]{12}{*}{1002} & January & 21.5 & 23.6 & 24.8 \\
\hline & February & 18.0 & 22.3 & 21.7 \\
\hline & March & 21.6 & 23.8 & 25.4 \\
\hline & April & 19.5 & 23.3 & 24.8 \\
\hline & May & 22.3 & 25.1 & 27.3 \\
\hline & June & 22.7 & 24.3 & 25.1 \\
\hline & wuly & 19.7 & 22.7 & 23.8 \\
\hline & August & 18.1 & 20.9 & 21.8 \\
\hline & September & 16.8 & 18.6 & 19.3 \\
\hline & October & 16.4 & 18.4 & 20.4 \\
\hline & Novelinber & 19.3 & 19.8 & 22.6 \\
\hline & Decomber & 23.8 & 22.3 & 26.2 \\
\hline \multirow[t]{12}{*}{1093} & January & 24.5 & 24.1 & 26.8 \\
\hline & Fobnary & 19.7 & 22.2 & 24.6 \\
\hline & March & 23.6 & 25.4 & 27.1 \\
\hline & April & 25.2 & 24.3 & 26.2 \\
\hline & May & NA & 25.0 & 28.3 \\
\hline & June & NA & 24.9 & 26.3 \\
\hline & wily & NA & 23.3 & 24.2 \\
\hline & August & NA & 21.3 & 22.4 \\
\hline & Soptomber & NA & 18.9 & 20.6 \\
\hline & October & NA & 10.0 & 20.8 \\
\hline & Nowernber & NA & 20.4 & 22.6 \\
\hline & Decomber & NA & 23.6 & 26.2 \\
\hline
\end{tabular}

Noles: All torecasts are besed on ectud generation and precipitation data through the indicated year. W/ krecasts essume normal preapitation during the torecast period.

Source: 8TEO Forceasts: Energy Information Administration, Office of Cod, Nutear, Electric, and Ahemate Fuets memo to Ofice of Energy Markess and End Use dated March 6, 1092. 8THGM Forecasts: Energy Information Administration, STHGM nun using HYDRO.TIME.SERIES.FINAL.D060183. Actual: En qy Information Administradion, Form ElA-759, "Monthly Power Plant Roport." 


\section{Appendix D. Census Divisions}

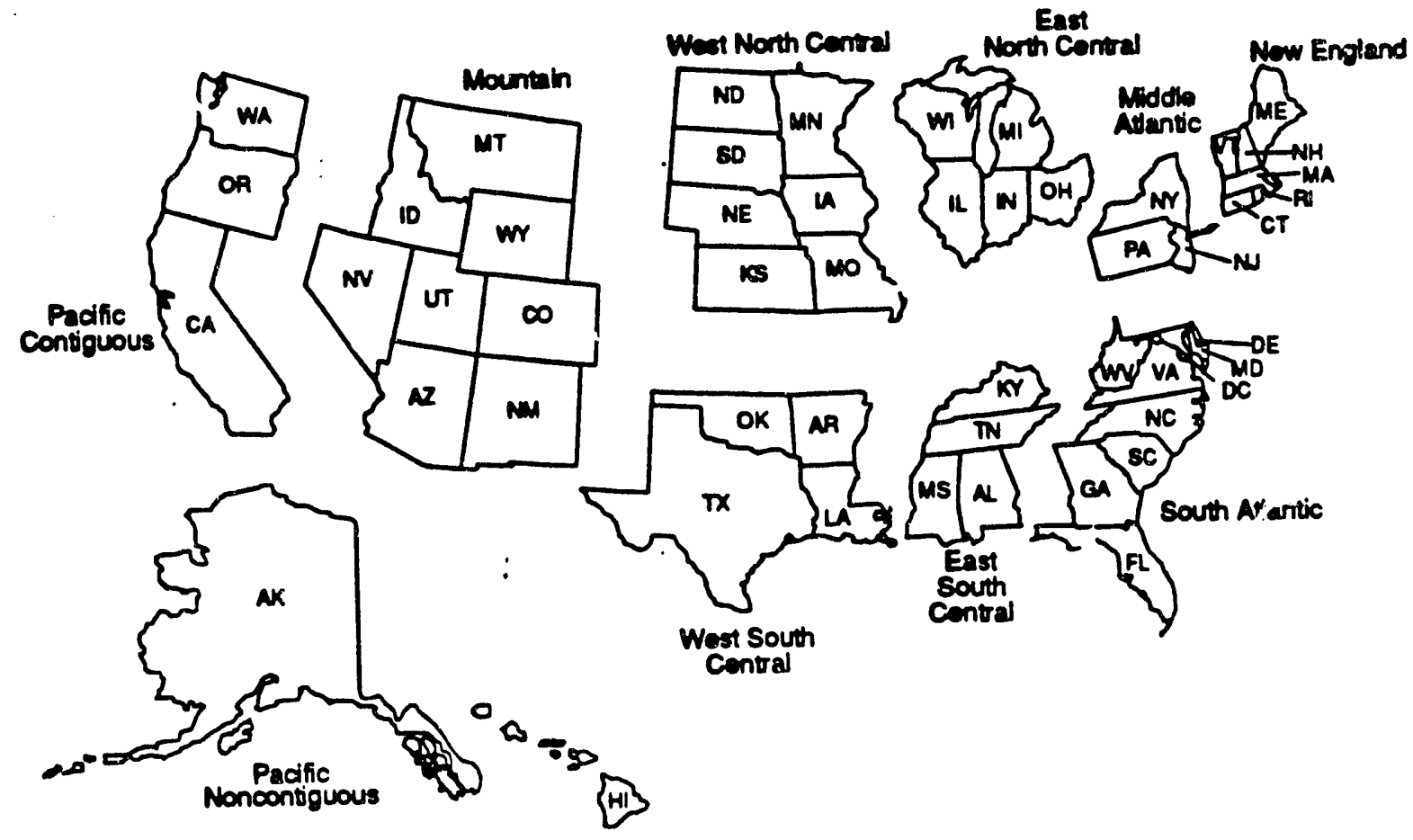

Source: United States Bureau of the Census. 

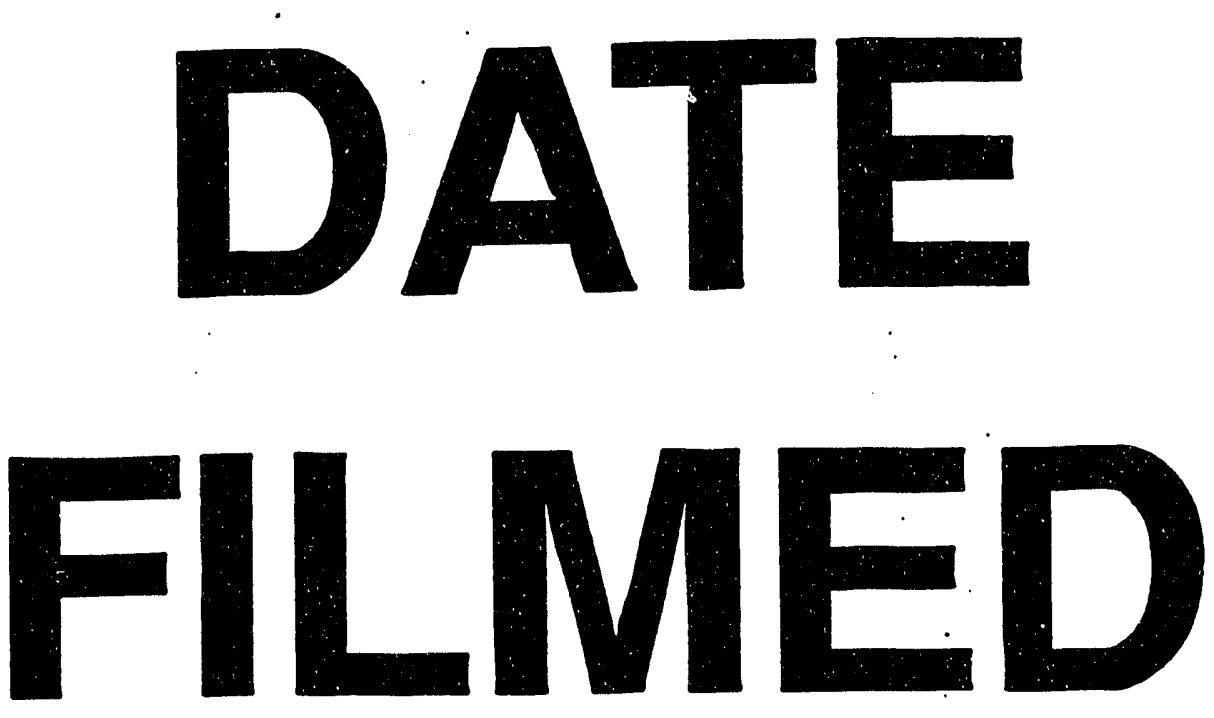

$11 / 17 / 93$
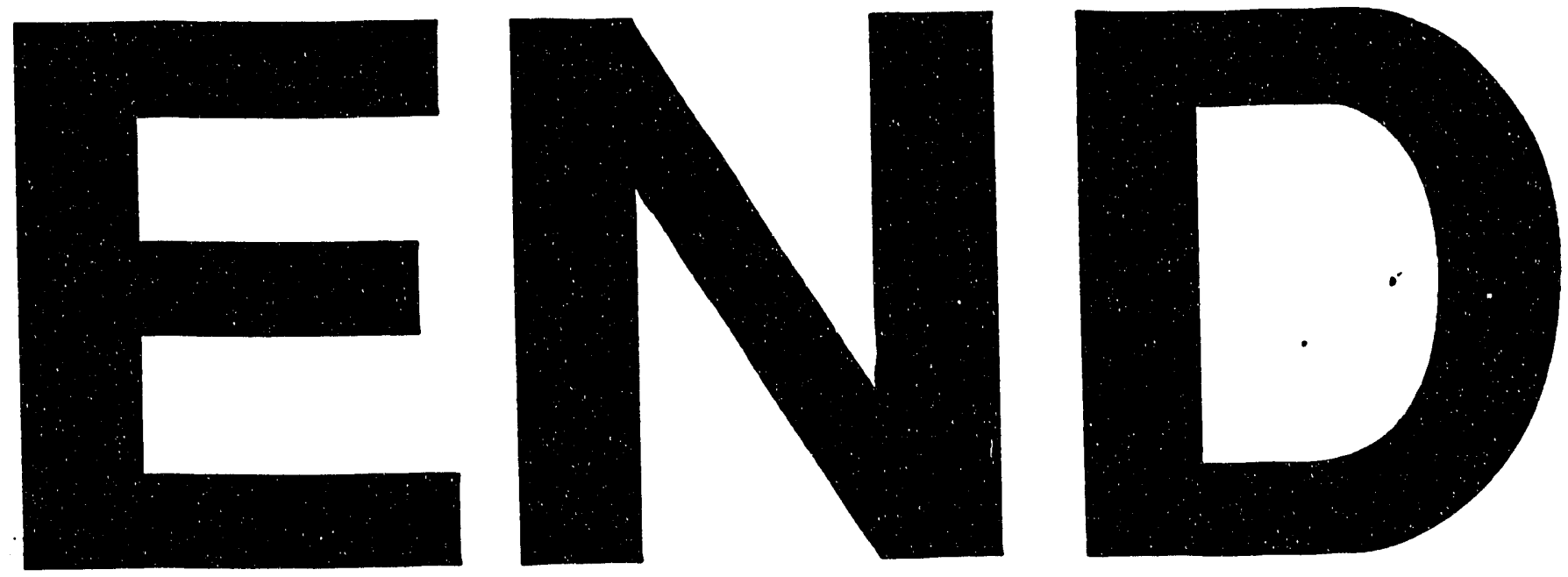
